\title{
Densities, distribution and detectability of a small nocturnal primate (Javan slow loris Nycticebus javanicus) in a montane rainforest
}

\author{
K. Anne-Isola Nekaris ${ }^{1}$, Jarot Arisona Aji Pambudi ${ }^{2}$, Dwi Susanto ${ }^{2}$, \\ Ridwan Djaffar Ahmad ${ }^{1,2}$, Vincent Nijman ${ }^{1, *}$ \\ ${ }^{1}$ Noctural Primate Research Group, Oxford Brookes University, OX3 0BP Oxford, UK \\ ${ }^{2}$ Department of Biology, Faculty of Mathematics and Natural Sciences, Universitas Indonesia, Depok 16424, Indonesia
}

\begin{abstract}
Nocturnal mammals can be challenging to survey and, especially for many species that live in dense forest habitats, limited information is available on densities and distributions. We surveyed the endemic Javan slow loris Nycticebus javanicus in the montane forests of Mount Gede Pangrango, West Java, Indonesia. Surveys were conducted on 23 transects ( $260 \mathrm{~h}$ covering some $93 \mathrm{~km}$ ) walking at variable speeds between 200 and $800 \mathrm{~m} \mathrm{~h}^{-1}$. Densities on individual transects varied from 0 to 52 ind. $\mathrm{km}^{-2}$, with an overall density of 15.6 ind. $\mathrm{km}^{-2}$ (95\% CI 9.7 to 25.2 ind. $\mathrm{km}^{-2}$ ). Encounter rates per kilometre were strongly influenced by the speed at which transects were walked, with fewer lorises detected at higher speeds. This effect was absent when considering encounter rates per hour. Detectability and behavior of Javan slow lorises were not affected by the amount of lunar light and, in contrast to studies of some of their congeners, we found no evidence of lunar phobia or lunar philia. Our study shows that slow lorises are not homogeneously distributed in their montane habitat and occur at intermediate densities. However, encounter rates did not differ between disturbed and primary forest. Analysis of data from multiple surveys of lorisforms, including this one, reveals no statistically significant relationship between survey effort or the speed at which transects are walked and estimated densities, but speed is positively correlated with encounter rates.
\end{abstract}

KEY WORDS: Indonesia $\cdot$ Survey methods $\cdot$ Lunar phobia $\cdot$ Mammal $\cdot$ Conservation $\cdot$ Ecology

\section{INTRODUCTION}

Surveying animals in a forest environment poses serious challenges, since the animals live in a 3dimensional environment (in the tropical rainforest up to heights of 30 to $40 \mathrm{~m}$ in the canopy) and humans, normally, are confined to the forest floor (Davey 1990). Likewise, surveying animals at night can be demanding for an essentially diurnal primate like we humans (Charles-Dominique \& Bearder 1979, Duckworth 1998). Numerous studies on night shift workers have shown that concentration levels, cognitive abilities and reflexes may be reduced at night (Åkerstedt 1990, Carpentier \& Cazamian 1990, Burgess et al. 2002). When the animals to be surveyed are not only nocturnal but also small, cryptic, arboreal and living in rugged terrain, it is difficult to envisage how vital population data can be systematically collected. Yet, or perhaps because of this, some of the least known and potentially rarest animals are nocturnal and forest-dwelling, making it all the more imperative to undertake these studies.

In addition to the challenging environment and the perils of working at night, the behaviour of the animals and that of the surveyor (e.g. speed at which surveys are conducted) both strongly influencee 
detectability, again possibly more so during the night than in the day. As noted by Starr et al. (2012) the sensory world of the forest at night has strongly influenced the behaviour and physiology of nocturnal mammals. In the absence of visual sensory cues, the activity patterns of many nocturnal mammals are affected by the intensity of nocturnal illumination. Depending on how vulnerable the animals are under bright moonlight, this may lead to a reduction (lunar phobic), an increase (lunar philic), or no change (lunar neutrality) in activity with increasing moon luminosity (Gannon \& Willig 1997, Gursky 2003, Nash 2007, Starr et al. 2011). Likewise, activity patterns may differ seasonally, or over time, with, for instance, animals becoming less active during certain parts of the reproductive cycle (e.g. Eads et al. 2012). The amount of moonlight has an effect on detectability of nocturnal mammals. Not only can surveyors see more, but also, based on the above, the increase or decrease in activity makes animals more or less visible. This may have important implications for the generalisation of conclusions drawn from individual studies.

Slow lorises (genus Nycticebus) are a group of nocturnal cryptic species confined to South and Southeast Asia (from India and China south to Indonesia and the Philippines). All are threatened by a combination of habitat loss and over-exploitation for medicinal and pet trades (Johns 1986, Nekaris \& Jaffe 2007 , Nekaris \& Nijman 2007, Thorn et al. 2009, Starr et al. 2011, Nekaris et al. 2013a). Currently 8 species are recognised, most of them living allopatrically (Nijman \& Nekaris 2010). Extensive sympatry is seen between the pygmy slow loris $N$. pygmaeus and Bengal slow loris $N$. bengalensis in Indochina (Nekaris 2013) and, to a lesser extent, possibly between Kayan slow loris $N$. kayan and Philippine slow loris $N$. menagensis in Borneo (Munds et al. 2013). The southernmost species of slow loris is the Javan slow loris N. javanicus, confined to the island of Java, Indonesia. Compared to other slow lorises, it has been little studied. A substantial amount of our knowledge is derived from animals being traded as pets (Nekaris \& Jaffe 2007), and indeed this threat is deemed so severe that the species has recently been included on the list of the top 25 most endangered primates (Nekaris et al. 2008, Nekaris \& Shekelle 2008b, 2013b). Given the paucity of knowledge on wild Javan slow loris, and the limited number of systematic studies addressing the problems of detectability when studying nocturnal rainforest mammals, including threatened species such as the Javan slow loris, our study focused on this species.
The aim of this study is firstly to report on the presence and distribution of Javan slow lorises in Mount Gede Pangrango National Park, West Java and to present tentative data on the densities and the population size of the slow lorises in our study area. Secondly, we present data on the relationship between detectability (number of individuals detected per unit of survey effort) and variables such as speed at which transects are walked, habitat, and moon phase. While the first part is of relevance for increasing our understanding of Javan slow lorises, and indeed lorisiforms in general, the second part of our study should be of relevance to all those who survey nocturnal animals.

\section{MATERIALS AND METHODS}

\section{Study species}

The Javan slow loris was for a long time considered conspecific with other slow lorises but recent molecular work has demonstrated it to be a sister species of the Bengal slow loris, and clearly differentiated from other insular Southeast Asian slow lorises (Roos 2003). Formerly it was considered to be restricted to the western and central parts of the island as far as Lebakharjo in East Java (Thorn et al. 2009), but recent surveys have confirmed its presence in the easternmost part of the island as well (K. A. I. Nekaris unpubl. data). The Javan slow loris is easily identified by a prominent, white diamond-shaped pattern on the forehead formed by a distinct dark-brown stripe that runs over its head that splits towards both eyes and ears. Like all slow lorises, the eyes have a reflective layer (tapetum lucidum) and, when shone upon by a torch, the eyes and the white on the face make the species instantly recognisable. Adult body mass is between 600 and $800 \mathrm{~g}$ with a body length of some $30 \mathrm{~cm}$. Males can be distinguished from females by their prominent testicles. Especially when using lights with red filters, slow lorises can be observed at ease, allowing for accurate identification. Javan slow lorises are largely arboreal and can be found in primary and secondary forest, bamboo and agroforests from sea level up to $\sim 1700 \mathrm{~m}$ a.s.l. (Thorn et al. 2009, K. A. I. Nekaris unpubl. data).

\section{Study area}

We studied Javan slow lorises in Mount Gede Pangrango National Park in West Java, in the western 
part of the distribution range of the species. Mount Gede Pangrango is Indonesia's oldest nature reserve. It consists mainly of montane forest and includes the well-known botanical gardens of Cibodas and the multi-coloured lake Telaga Warna. It covers an area of $\sim 150 \mathrm{~km}^{2}$ with an additional 20 to $40 \mathrm{~km}^{2}$ of degraded forest situated outside the park borders (Nijman et al. 2000). While in most forest areas Javan slow lorises are known from single observations, we have records of slow lorises at various localities on Mount Gede Pangrango, including at Cibodas ( 1400 m a.s.l.), Telaga Warna ( 1600 m), Selabintana $(\sim 900 \mathrm{~m})$ and Bodogol ( 800 m ). The latter site was chosen as our study area because of its ease of access and the nearby presence of the Bodogol Conservation Education Center. The study area covers $\sim 4.5 \mathrm{~km}^{2}$ of 2 valleys, with the forest in the lower parts of the valleys descending to $\sim 600 \mathrm{~m}$ and steep slopes restricting access further into the valley above $\sim 1000 \mathrm{~m}$.

The forest at Bodogol is characterised as a transition between lowland and lower montane forest (Helmi et al. 2009). The forest is dominated by Schima wallichii (Theaceae), Pternandra caerulescens (Melastomataceae), Neesia altissima (Bombacaceae), Luvunga sarmentosa (Rutaceae) and Maesopsis eminii (Rhamnaceae: introduced). The presence of the latter species, other exotics (Cecropia peltata), and the prominence of pioneer species (Macaranga sp., Mallotus sp.) are indicative that the forest has been disturbed.

The climate in the study area is perhumid. The average annual rainfall measured at the nearest meteorological station (Tapos, $10 \mathrm{~km}$ north of Bodogol, at $806 \mathrm{~m}$ a.s.l.), is close to $4000 \mathrm{~mm}$, with little seasonal variation. Even during the driest months (July to September) average monthly rainfall is $\sim 200 \mathrm{~mm}$.

\section{Data acquisition and analysis}

Surveys were undertaken over a 4 wk period in April to May 2006 (by K. A. N. and J. A. A. P.), and from the end of July until mid-September 2006 (by J. A. A. P., D. S. and D. A.), with transect walks conducted on 45 nights. While our study period coincided with the less wet season, frequent rain and incoming clouds and mist prevented surveys later during the night, and surveys were conducted between 18:00 and 24:00 $\mathrm{h}$ for some $6 \mathrm{~h}$ of surveying per night. The data we have on Javan slow lorises does not suggest that the 'dry' season coincides with periods of heightened or lowered activities, or with a birth or mating season (K. A. I. Nekaris unpubl. data).

Surveys were concentrated on 23 (partial) transects for a total of $260 \mathrm{~h}$ covering some $93 \mathrm{~km}$. The transects were between 0.5 and $2.0 \mathrm{~km}$ in length, with one longer one of $4.7 \mathrm{~km}$. The nature of the terrain did not allow us to establish transects of equal lengths, unless we chose them to be all fairly short, hence we followed the recommendations made by Buckland et al. (2010) to vary the transect lengths. The speed walked along transects varied among surveys, with the majority of surveys conducted at speeds between 200 and $550 \mathrm{~m} \mathrm{~h}^{-1}$. Each survey was conducted by a team of 2 people carrying head torches with red filters, checking both sides of the transect and regularly checking behind them to assure no animals were missed.

As indicated above, the forests in the study area are not all pristine and, based on observed characteristics, we grouped transects into those occurring mainly or exclusively in secondary forest, mainly or exclusively in primary forest or in a combination of both. Whilst, in terms of elevation, the highest transect was in pristine forest and the lowest in secondary forest, there was considerable altitudinal overlap between the 2 habitat types.

Eleven transects were walked multiple times, and these were used to explore the relationship between detectability of slow lorises (number of individuals per unit of survey effect) and survey effort (length in kilometres, or time in hours). On average, these 11 transects were walked 5.8 times (range 3 to 13 times), with each individual transect walked at a different range of speeds. Spatially the 11 transects were a representative subset of the total number of transects. They were not confined to a particular part of the study area; for instance, they covered the full altitudinal range of the study area from 600 to $1000 \mathrm{~m}$ a.s.l.

The activity patterns of slow lorises and indeed other lorisiformes are affected by the amount of lunar light, with lower levels of activity during bright moonlit nights (Bearder et al. 2006). This difference in activity may affect detectability. We obtained data on the lunar phase for each of our survey nights from the Moon Phase Calculator (www.timeanddate.com/ calendar/moonphases.html) using Jakarta as our point of reference (Indonesia's capital, located at the same longitude as the study site). All surveys were conducted prior to midnight and we transferred lunar phases to a scoring system from 1 (full moon) to 0 (new moon and, considering that surveys were conducted prior to midnight, the third quarter). Note that, while inside the forest, the canopy cover can 
obscure the moon, and at a micro-scale there are clear differences in illumination on moonlit nights, but overall even inside the forest the effect of the moon is clearly observable. Some studies, for instance Eads et al. (2012) have explored the effects (in their case on black-footed ferrets Mustela nigripes) of whether or not the moon is above the horizon on the survey night and found this to have a clear measurable effect. We grouped survey nights into those with or without the moon above the horizon during the survey and compared encounter rates.

Finally, we tested whether or not there was a temporal component to detectability. We tested whether slow lorises were more easily detected during the beginning of the study period (April to May), in the middle (July) or at the end (August to September) by comparing encounter rates.

Slow lorises were recorded mainly by their reflective eye-shine, and upon detection the perpendicular distance to the transect line was estimated visually to the nearest meter. We did not use eyeshine to identify slow lorises, since we mainly used red lights to conduct our surveys, making eyeshine of all species appear reddish. Rather, animals were identified by their physical appearance. We used Distance software (Buckland et al. 2001) to calculate densities, using all transects and all repeats, and to estimate the population size in the study area.

All data were checked for normality and if they deviated significantly from a normal distribution were log-transformed so as to approach a normal distribution more closely. All subsequent statistical tests were parametric (1-way analysis of variance, $t$-tests, Pearson's product moment correlations) with significance accepted when $\mathrm{p}<0.05$ in a 2-tailed test. Results are presented as mean $\pm 1 \mathrm{SE}$ or $95 \%$ confidence intervals (CI).

\section{RESULTS}

\section{Density and distribution}

Slow lorises are sparsely but widely distributed in the Bodogol valleys. We found them at altitudes between 656 and $980 \mathrm{~m}$ a.s.l.; the average altitude at which the slow lorises were first detected was $757 \pm$ $8 \mathrm{~m}$ (range 731 to $931 \mathrm{~m}, \mathrm{n}=21$ ). There was no difference between the primary and secondary forest in terms of the altitude at which slow lorises were first detected ( $t$-test, $t=1.78, \mathrm{df}=19, \mathrm{p}=0.09$ ). We have recorded Javan slow lorises at elevations of up to $1600 \mathrm{~m}$ a.s.l on the northern slopes of Mount Gede-
Pangrango (V. Nijman pers. obs.) but, as stated above, access in the Bodogol valley is restricted to elevations below $1000 \mathrm{~m}$. Javan slow lorises used all forest strata, with individuals observed from $1 \mathrm{~m}$ above the ground up to an estimated height of $27 \mathrm{~m}$ in the tree (average $8 \pm 1 \mathrm{~m}, \mathrm{n}=33$; because of step slopes we were not able to estimate the height in the ree for 4 slow lorises). We did not observe them on the ground, noting however that connectivity is high in the study area, allowing the slow lorises to remain arboreal at all times.

On 25 occasions, a total of 37 slow lorises were detected along the transect lines. On 17 occasions, single individuals ( 5 males, 5 females, 7 unknown sex) were observed and on 8 occasions 2 individuals were seen in close proximity to one another. Of the latter, 5 pairs comprised an adult male with an adult female; the other 3 pairs were a mother with infant, 2 subadults of unknown sex, and 2 adults of unknown sex.

Perpendicular distances (i.e. the straight angle distance between the transect line and the slow loris upon first detection) did not differ between primary and secondary forest (ranges 4 to $22 \mathrm{~m}$ and 1 to $19 \mathrm{~m}$, respectively) ( $t$-test, $t=1.54, \mathrm{df}=27, \mathrm{p}=0.13$ ) A halfnormal model with cosine adjustment was found to best fit our data and, using perpendicular distances from both primary and secondary forest, we estimated the effective strip width at $13 \mathrm{~m}(95 \%$ CI 10 to $16 \mathrm{~m})$. Densities on individual transects varied from zero (with a survey effort between 1.5 and $3.4 \mathrm{~km}$ ) to 52 ind. $\mathrm{km}^{-2}$ (based on $3.7 \mathrm{~km}$ effort), resulting in an overall density of 15.6 ind. $\mathrm{km}^{-2}$ (95\% CI 9.7 to 25.2 ind. $\mathrm{km}^{-2}$ ). These data suggest a population of some 70 slow lorises in our $4.5 \mathrm{~km}^{2}$ study area. Note, however, that the Bodogol valley is not isolated from the remainder of Mount Gede Pangrango National Park, and the total population on the mountain comprised more individuals.

\section{Detectability}

We found no effect of seasonality on the encounter rates with slow lorises, with no differences between the beginning of our study (April to May, $0.43 \pm$ $0.23 \mathrm{~km}^{-1}$ ), the middle (July, $0.48 \pm 0.11 \mathrm{~km}^{-1}$ ) or the end (August to September, $\left.0.69 \pm 0.28 \mathrm{~km}^{-1}\right)$ (1-way ANOVA, $\left.F_{2,60}=0.31, \mathrm{p}=0.74\right)$. The number of slow lorises detected per kilometre was strongly influenced by the speed at which transects were walked (Fig. 1). The number of slow lorises detected per kilometre surveyed declined progressively as transects were walked faster $\left(F_{1,5}=17.3, \mathrm{p}=0.01\right)$. Even walk- 


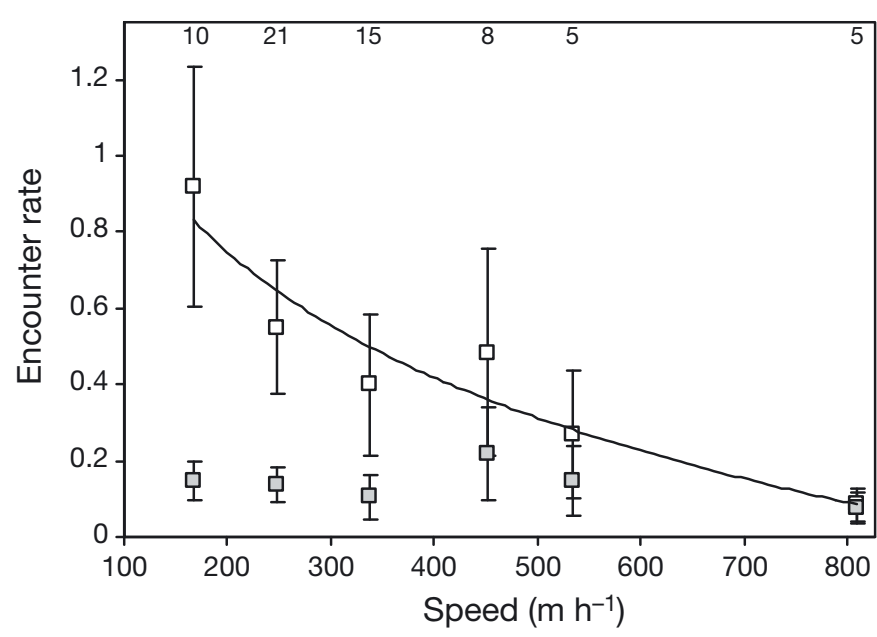

Fig. 1. Nycticebus javanicus. Relationship between the speed at which transects were walked and encounter rates (mean \pm SE) of slow lorises per kilometre $(\square)$ and per hour $(\square)$. The trend line indicates the highly significant exponential decrease of encounter rate per kilometre at higher walking speeds. Numbers above data points indicate the number of surveys carried out at the corresponding speed

ing transects at a relatively leisurely pace of 500 to $800 \mathrm{~m} \mathrm{~h}^{-1}$ led to a marked decrease in encounter rates per kilometre. However, encounter rates per hour surveyed were not influenced by the speed at which the transects were walked $\left(F_{1,5}=0.64, \mathrm{p}=\right.$ $0.47)$.

There was no difference between the speeds walked along transects in primary or secondary for-

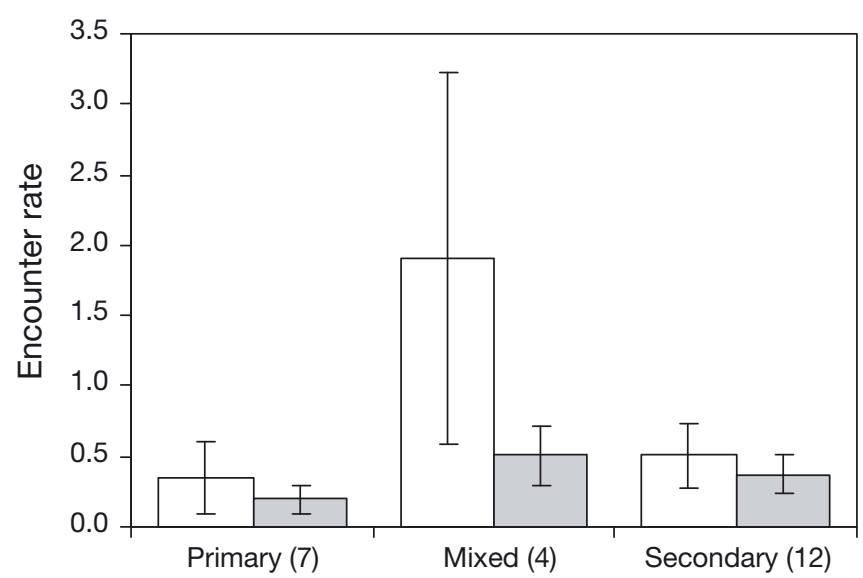

Fig. 2. Nycticebus javanicus. Encounter rates (mean $\pm \mathrm{SE}$ ) of Javan slow lorises on transects occurring mainly or exclusively in primary forest, mainly or exclusively in secondary forest or in a parentheses of both. Numbers of transects are indicated in brackets. Encounter rates are expressed per kilometre (open bars) or per 3 hours (grey bars) of survey effort. None of the differences are statistically significant est $(t$-test, $t=0.892, \mathrm{df}=62, \mathrm{p}=0.38)$. Average encounter rates did not differ statistically among transects occurring mainly or exclusively in primary forest, mainly or exclusively in secondary forest or in a combination of both $\left(F_{2,20}=2.336, \mathrm{p}=0.12\right.$ and $F_{2,20}=0.841, \mathrm{p}=0.45$, for encounter rates per kilometre and per hour, respectively) (Fig. 2)

Detectability of Javan slow lorises did not appear to be affected by the amount of lunar illumination (Fig. 3) and we found no obvious evidence that slow loris behaviour was linked to moonlight. We found no difference in encounter rates on nights when the moon was above the horizon and nights when it was not $(t$-test, $t=1.15, \mathrm{df}=33, \mathrm{p}=0.26)$. There was no significant relationship between lunar score and encounter rate per kilometre $\left(F_{1,62}=1.272, \mathrm{p}=0.26\right)$ or per hour $\left(F_{1,62}=0.134, \mathrm{p}=0.72\right)$. Likewise on nights without or with very little moonlight (new moon, third quarter or waxing crescent) encounter rates did not differ from those of nights with moonlight ( $t$-test, $t=0.788, \mathrm{df}=62, \mathrm{p}=0.43$, and $t=0.144$, $\mathrm{df}=62, \mathrm{p}=0.89$, for encounter rates per kilometre and per hour, respectively).

Comparisons with other studies (Table 1) that estimated densities of lorisiformes show that the density of slow lorises found on Mount Gede Pangrango appears to be fairly typical. With respect to surveying, the analysis of data from multiple surveys of lorisforms, including this one, reveals no relationship between survey effort and density (Pearson's product moment correlation $\rho=-0.44, \mathrm{n}=7, \mathrm{p}=0.32$ for sur-

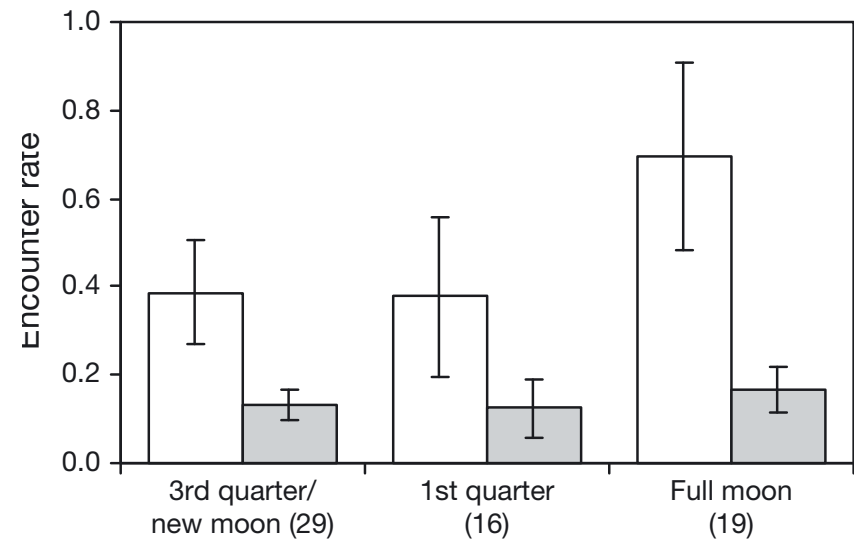

Fig. 3. Nycticebus javanicus. Encounter rates (mean $\pm \mathrm{SE}$ ) of Javan slow lorises on nights with no or very little moonlight (third quarter and new moon), small amounts of moonlight (first quarter) and moonlit nights (full moon). Numbers of nights are indicated in parentheses. Encounter rates are expressed per kilometre (open bars) or per 3 hours (grey bars) of survey effort. None of the differences are statistically significant 
Table 1. Selected studies reporting densities of lorisiforms based on line transects and calculated using the Distance programme. Speed refers to the average speed at which transects were walked. nd: no data

\begin{tabular}{|c|c|c|c|c|c|c|c|}
\hline Species & Study area & $\begin{array}{l}\text { Survey effort } \\
\text { (nights) }\end{array}$ & $\begin{array}{l}\text { Survey } \\
\text { effort }(\mathrm{km})\end{array}$ & $\begin{array}{c}\text { Speed } \\
\left(\mathrm{km} \mathrm{h}^{-1}\right)\end{array}$ & $\begin{array}{l}\text { Encounters } \\
\text { (n) }\end{array}$ & $\begin{array}{c}\text { Density } \\
\text { (ind. } \mathrm{km}^{-2} \text { ) }\end{array}$ & Reference \\
\hline $\begin{array}{l}\text { Calabar angwantibos } \\
\text { Arctocebus calabarensis }\end{array}$ & Rhoko forest, Nigeria & 60 & 136 & 0.6 & 29 & 13 & Schein (2008) \\
\hline $\begin{array}{l}\text { Potto } \\
\text { Perodicticus potto }\end{array}$ & Ituri Forest, DR Congo & 44 & 86 & 0.5 & 25 & 29.5 & Robjent (2005) \\
\hline $\begin{array}{l}\text { Javan slow loris } \\
\text { Nycticebus javanicus }\end{array}$ & $\begin{array}{l}\text { Gede Pangrango National } \\
\text { Park, Indonesia }\end{array}$ & 45 & 93 & $0.2-0.8$ & 37 & 15.6 & This study \\
\hline $\begin{array}{l}\text { Greater slow loris } \\
\text { N. coucang }\end{array}$ & $\begin{array}{l}\text { Tekam Forest (primary), } \\
\text { Malaysia }\end{array}$ & 228 & nd & nd & nd & 23.7 & $\begin{array}{l}\text { Nekaris et al. } \\
(2008 a)^{\mathrm{a}}\end{array}$ \\
\hline $\begin{array}{l}\text { Bengal slow loris } \\
N \text {. bengalensis }\end{array}$ & $\begin{array}{l}\text { Khao Ang Rue Nai, } \\
\text { Thailand }\end{array}$ & 77 & 184 & $1.0-1.5$ & 105 & 2.7 & $\begin{array}{l}\text { Pliosungnoen et } \\
\text { al. (2010) }\end{array}$ \\
\hline $\begin{array}{l}\text { Red slender loris } \\
\text { Loris tardigradus }\end{array}$ & $\begin{array}{l}\text { Dandeniya-Masmullah, } \\
\text { Sri Lanka }\end{array}$ & 72 & 180 & 0.5 & 44 & 31 & $\begin{array}{l}\text { Nekaris \& } \\
\text { Stengel (2013) }\end{array}$ \\
\hline Grey slender loris & Devrayandurga, India & $\sim 10$ & 36 & 1.8 & 41 & 16 & Das et al. (2011) \\
\hline L. lydekkerianus & Ujjani-Savanadurga, India & $\sim 12$ & 62 & 1.8 & 252 & 185 & \\
\hline
\end{tabular}

vey effort in kilometres, and $\rho=-0.40, \mathrm{n}=8, \mathrm{p}=0.33$ for survey effort in number of nights). Hence, it appears that there is no evidence of an increase or decrease in estimated densities due to increased sampling, nor is there evidence of prolonged research efforts in areas of high or low densities. The average speed at which transects were walked bears no relationship with estimated densities $(\rho=-0.18$, $\mathrm{n}=7, \mathrm{p}=0.70$ ) but the encounter rate (data not shown) is positively correlated with the speed at which transects were walked $(\rho=0.82, n=7, p=0.02$ and $\rho=0.88, n=7, p=0.01$, for encounter rates per kilometre and per hour, respectively).

\section{DISCUSSION}

\section{Densities and abundance}

The density calculated for slow lorises is one of the few available for lorisiformes (Nekaris 2013). Table 1 shows estimates of population densities for lorises, angwantibos and pottos based on transect walks and calculated using Distance software (inclusion of density estimates based on, for instance, home range mapping may be strongly biased towards areas where the species of interest is particularly abundant). Our estimate of around 16 ind. $\mathrm{km}^{-2}$ appears to be fairly typical: compared to the results of our study, both higher and lower densities are reported for slender lorises and other slow lorises, while higher and lower densities are reported for pottos and angwantibos respectively.

The overall encounter rate on Mount Gede Pangrango, as a naïve estimate of abundance sensu Nekaris et al. (2008a), was 0.40 ind. $\mathrm{km}^{-1}$ (37 ind. sighted during $93 \mathrm{~km}$ of transect walks). This compares well to overall encounter rates of other species (Nycticebus coucang: 0.66 to 0.74 ind. $\mathrm{km}^{-1} ;$ N. bengalensis: 0.10 to 0.13 ind. $\mathrm{km}^{-1} ; N$. menagensis: 0.12 ind. $\mathrm{km}^{-1} ;$ N. pygmaeus: 0.05 to 0.08 ind. $\mathrm{km}^{-1}$; see Nekaris \& Nijman 2007). However, as indicated in 'Materials and methods', we specifically selected Mount Gede Pangrango as our study site because there were a large number of records of slow lorises on this mountain. We have no hard data to suggest that slow lorises are particularly abundant on Mount Gede Pangrango but we acknowledge that this may be the case and wish to caution against extrapolating the results from our study to other areas in Java. Javan slow lorises occur all over Java where some form of forest cover remains, but abundances appear to be linked to levels of hunting and the strength of taboos against collecting them (Nijman et al. 2014, this issue). Climatic conditions on Java differ greatly, even over small geographic distances. Some areas, such as Mount Gede Pangrango, receive large amounts of rainfall and support lush tropical rainforest. Other parts, including Java's north coast and eastern Java have a marked dry season and the remaining natural vegetation is deciduous. We expect that these differences in vegetation and cli- 
matic conditions have an effect on the spacing pattern, distribution and densities of Javan slow lorises.

\section{Ecology and habitat use}

We recorded slow lorises roughly between altitudes of 600 to $1000 \mathrm{~m}$ a.s.l., which spanned the entire range of forest which we were physically able to survey. The forest on Mount Gede Pangrango does not descend below $600 \mathrm{~m}$ (in fact in most parts the forest line is at considerably higher elevations) but we have records of slow lorises up to $1600 \mathrm{~m}$ on other parts of Mount Gede Pangrango. While Java is situated close to the equator and generally experiences a hot tropical climate it is worth noting that the climate on mountains is in some respect more reminiscent of temperate areas. The temperature decreases $\sim 0.6^{\circ} \mathrm{C}$ for a rise of $100 \mathrm{~m}$ (Braak 1929) and heat is lost more quickly from high altitudes at night resulting in greater daily temperature fluctuations, compared to lower elevations. The upper limit of the altitudinal distribution range of Javan slow loris coincides with the lower limit of where ground frost due to nocturnal radiation occurs (Domrös 1976).

We found slow lorises to be completely arboreal in our study area and we never observed one on the ground. They utilised the entire range from low bushes and saplings at eye level to the upper canopy of some of the taller trees. While the forests on this part of Mount Gede Pangrango are not all pristine, the connectivity and availability of interconnecting branches was high, allowing the animals to remain arboreal at all times. For greater slow loris Nycticebus coucang in Malaysia, Johns (1986) reported a higher encounter rate in edge habitat than in the forest interior on a survey route that included equal areas of these habitat types. Voskamp et al. (2014) found Javan slow lorises in completely human-modified landscapes and even suggest that such habitats may be preferred. Nekaris et al. (2008a) show that slow lorises occur in many habitat types, from acacia woodland to montane mist forest. We detected Javan slow lorises both in the primary forest and in more disturbed areas, and our data do not suggest a difference in habitat use between these forest types. Detectability studies have been little used for slow loris studies, generally because sample sizes of detections are too low. We encourage, however, the addition of some element of comparison of detectability across study sites in order to assess more accurately the conservation status of these extremely ecologically generalised slow loris species.

\section{Surveying at night}

We found no evidence for either lunar phobia or lunar philia in Javan slow lorises, neither when correlating encounter rates with lunar scores nor when comparing encounter rates between nights without moonlight, nights with small amounts of moonlight and moonlit nights. This is somewhat in contrast to data reported on other slow lorises; however we caution against direct comparisons, as survey methodologies differ between studies. Trent et al. (1977), in a study of captive animals, reported greater slow lorises to be lunar phobic. Starr et al. (2012) reported that wild pygmy slow lorises were clearly lunar phobic during the dry cool season, but showed lunar neutrality during the colder wet season. For wild slender lorises Loris tardigradus, Bearder et al. (2002) noted that they called more frequently during moonlit nights and that they increased foraging and travelling during full moon, suggesting that slender lorises are lunar philic. While surveying, we noted clear differences in levels of moonlight even within the rainforest but it is evident that these differences are more marked in areas without a dense canopy cover. It is quite possible that Javan slow lorises living in more open habitats such as agroforest or deciduous forests during the dry season do show lunar phobia as seen in pygmy slow lorises but this obviously requires more focused research.

The results of the present study provide no indication that the behaviour of the slow lorises on Mount Gede Pangrango has a noticeable effect on detectability; however, the behaviour of the surveyor clearly has. During our study the encounter rates with slow lorises remained constant in time irrespective of the speed at which transects were walked. Encounter rates per distance walked decreased significantly when walking at a faster pace. Walking at a slower speed allows a surveyor to detect a larger proportion of the slow lorises present along the transect (possibly because a slower walking speed allows individuals to be detected at greater distances from the transect line, although we found no evidence for this) but on the other hand less ground can be covered. Walking at a greater speed obviously has the advantage that more ground can be covered but this evidently comes at a cost of detecting only a proportion of the animals present in the study area (and again, possibly non-detection of animals further away from the transect line). While this in itself is not remarkable, it is notable that we detected this effect even within the narrow range of speeds walked along the transects in our study: our highest survey 
speeds averaged no more than $800 \mathrm{~m} \mathrm{~h}^{-1}$, which is within the typical range of walking speeds in lorisiform surveys (see Table 1).

Duckworth (1998) and, to a lesser extent, Pliosungnoen et al. (2010) evaluated the potential and pitfalls of estimating densities for nocturnal mammals using distance sampling. They noted that one or more of the key assumptions of the method (see Buckland et al. 2001) were frequently violated, including (1) detection of all individuals on or above the transect line, (2) the possibility of obtaining adequate sample sizes, (3) the use of roads or paths as opposed to randomly placed transects and (4) multiple use of the same trails or transects. In our study we used 23 transects, which, because of the steepness of the terrain, were not randomly located but instead followed in part the topography of the area. Most transects were only walked once but others were walked multiple times to explore the effects of survey speed. Multiple use of the same trail is not too serious a problem, especially if walks are not made on consecutive nights: different individuals are likely to be seen on different nights, since one detects only a subset of the population every night. We agree with Pliosungnoen et al. (2010) that for a trained observer it is possible to detect most, if not all, slow lorises on the transect line. Our sample size of 37 encounters is lower than the 60 to 80 recommended by Duckworth (1998) but given the good fit of the model we feel that this is acceptable for calculating densities. It is clear that walking at too fast a pace, i.e. $>800 \mathrm{~m} \mathrm{~h}^{-1}$, will lead to slow lorises being missed, including ones on the transect line. When walking too slowly, i.e. $<300 \mathrm{~m} \mathrm{~h}^{-1}$, new animals may be detected without actually traversing more distance. Finally, the issue of non-detection of slow lorises on the transect line is perhaps less of a problem when walking at moderate speed (in our study area 300 to $500 \mathrm{~m} \mathrm{~h}^{-1}$ but this depends on the surveyor and especially the terrain), using red light (slow lorises cannot detect red lights and behave normally when illuminated by a red beam of light; the use of red light also minimizes avoidance behaviour by torch-shy animals), and surveying in a $360^{\circ}$ fashion (searching equally in a forward and backward direction).

Acknowledgements. We thank the Gunung Gede Pangrango park authorities and the staff of the Bodogol Conservation Education Center for supporting our studies. We thank Prof. Hadi S. Alikodra, Dr. Noviar Andayani, Prof. Simon Bearder, Dr. Andrew Grieser-Johns, Dr. Richard Moore, Broto Raharjo, Henriet Robjent, Leah Schein, Dr. Carly Starr, Dr. Jatna Supriatna and Fitriah Usman for data, information and support. Two reviewers provided construc- tive comments that improved clarity. Fieldwork was funded by BP Conservation Leadership Programme, Primate Conservation Inc., and IDEAWILD, R.D.A.'s visits to the Nocturnal Primate Research Group in Oxford were made possible through support from the Cambridge University's SCCS Internship Programme and Oxford Brookes University, and V.N.'s and K.A.I.N.'s visits to Universitas Indonesia were funded in part through the Oxford Brookes Universty Central Research Fund. K.A.I.N.'s research on Javan slow lorises is funded by the Leverhulme Trust (RGP 084) and V.N.'s work on Java was funded in part by the Zoological Museum Amsterdam. Finally we commend the editorial board of Endangered Species Research for commissioning this special issue on slow lorises as it allowed us to evaluate our data in a clearly defined context.

\section{LITERATURE CITED}

Åkerstedt T (1990) Psychological and psychophysiological effects of shift work. Scand J Work Environ Health 16 Suppl 1:67-73

Bearder SK, Nekaris KAI, Buzzell A (2002) Dangers in the night: Are some nocturnal primates afraid of the dark? In: Miller L (ed) Eat or be eaten: predatory sensitive foraging among primates. Cambridge University Press, Cambridge, p 21-43

> Bearder SK, Nekaris KAI, Curtis DJ (2006) A re-evaluation of the role of vision in the activity and communication of nocturnal primates. Folia Primatol (Basel) 77:50-71

Braak C (1929) On the climate of and meteorological research in the Netherlands Indies. In: Science in the Netherlands East Indies. Koninklijke Akademie van Wetenschappen, Amsterdam, p 50-64

Buckland ST, Anderson DR, Burnham KP, Laake JL, Borchers DL, Thomas L (2001) Introduction to distance sampling: estimating abundance of biological populations. Oxford University Press, Oxford

Buckland ST, Plumptre AJ, Thomas L, Rexstad EA (2010) Design and analysis of line transect surveys for primates. Int J Primatol 31:833-847

Burgess HJ, Sharkey KM, Eastman CI (2002) Bright light, dark and melatonin can promote circadian adaptation in night shift workers. Sleep Med Rev 6:407-420

Carpentier J, Cazamian P (1990) Night work: its effects on the health and welfare of the worker, 4th edn. International Labour Organisation, Geneva

Charles-Dominique P, Bearder SK (1979) Field studies of lorisid behavior: methodological aspects. In: Doyle GA, Martin RD (eds) The study of prosimian behavior. Academic Press, New York, NY, p 567-629

- Das S, Dutta S, Mangalam M, Verma RK, Rath S, Kumara HN, Singh M (2011) Prioritizing remnant forests for the conservation of Mysore slender lorises (Loris lyddekerianus lyddekerianus) in Karnataka, India through estimation of population density. Int J Primatol 32:1153-1160

$>$ Davey SM (1990) Methods for surveying the abundance and distribution of arboreal marsupials in a south coast forest of New South Wales. Wildl Res 17:427-445

> Domrös M (1976) Über das Vorkommen von Frost auf Java/ Indonesien, insbesondere in den Pengalengan Highlands. Erdkunde 30:97-108

$>$ Duckworth JW (1998) The difficulty of estimating population densities of nocturnal forest mammals from transect counts of animals. J Zool (Lond) 246:466-468 
Eads DA, Jachowski DS, Millspaugh JJ, Biggins DE (2012) Importance of lunar and temporal conditions for spotlight surveys of adult black-footed ferrets. West N Am Nat 72: 179-190

Gannon MR, Willig MR (1997) The effect of lunar illumination on movement and activity of the red fig-eating bat (Stenoderma rufum). Biotropica 29:525-529

Gursky S (2003) Lunar philia in a nocturnal primate. Int J Primatol 24:351-367

Helmi N, Kartawinata K, Samsoedin I (2009) An undescribed lowland natural forest at Bodogol, the Gunung Gede Pangarango National Park, Cibodas Biosphere Reserve, West Java, Indonesia. Reinwardtia 13:33-44

Johns A (1986) Effects of selective logging on the behavioral ecology of West Malaysian primates. Ecology 67:684-694

Munds RA, Nekaris KAI, Ford SM (2013) Taxonomy of the Bornean slow loris, with new species Nycticebus kayan (Primates, Lorisidae). Am J Primatol 75:46-56

Nash LT (2007) Moonlight and behavior in nocturnal and cathemeral primates, especially Lepilemur leucopus: illuminating possible anti-predator efforts. In Gursky SL, Nekaris KAI (eds) Primate anti-predator strategies. Springer, New York, NY, p 173-205

Nekaris KAI (2013) Lorisiformes. In: Mittermeier RA, Rylands AB, Wilson DE (eds) Mammals of the world. Vol 3. Primates. Lynxs Edicions, Barcelona, p 201-235

Nekaris KAI, Jaffe S (2007) Unexpected diversity of slow lorises (Nycticebus spp.) within the Javan pet trade: implications for slow loris taxonomy. Contrib Zool 76:187-196

Nekaris KAI, Nijman V (2007) CITES proposal highlights rarity of Asian nocturnal primates (Lorisidae: Nycticebus). Folia Primatol (Basel) 78:211-214

Nekaris KAI, Stengel CJ (2013) Where are they? Distribution and microhabitat use of fragments by red slender loris (Loris tardigradus tardigradus) in Sri Lanka. In: Marsh LK, Chapman CA (eds) Primates in fragments: complexity and resilience. Springer, New York, NY, p 371-384

Nekaris KAI, Blackham G, Nijman V (2008a) Conservation implications of low encounter rates of five nocturnal primates species (Nycticebus sp.) in Southeast Asia. Biodivers Conserv 17:733-747

Nekaris KAI, Llano Sanchez K, Thorn JS, Winarti I, Nijman V (2008b) Javan slow loris Nycticebus javanicus É. Geoffroy, 1812. In: Mittermeier RA, Wallis J, Rylands AB, Ganzhorn JU and others (eds) Primates in peril: the world's 25 most endangered primates 2008-2010. IUCN/ SSC Primate Specialist Group (PSG), International Primatological Society, and Conservation International,

Editorial responsibility: Carly Starr, Gatton, Australia
Arlington, VA, p 44-46

Nekaris KAI, Campbell N, Coggins TG, Rode EJ, Nijman V (2013a) Tickled to death: analysing public perceptions of 'cute' videos of threatened species (slow lorises - Nycticebus spp.) on Web 2.0 sites. PLoS ONE 8:e69215

Nekaris KAI, Shekelle M, Wirdateti, Rode EJ, Nijman (2013b) Nycticebus javanicus. In: IUCN Red List of Threatened Species. www.iucnredlist.org

> Nijman V, Nekaris KAI (2010) Checkerboard patterns, interspecific competition and extinction: lessons from distribution patterns of tarsiers and slow lorises in insular Southeast Asia. Int J Primatol 31:1147-1160

> Nijman V, van Balen S, Sözer R (2000) Breeding biology of Javan hawk-eagle Spizaetus bartelsi in West Java, Indonesia. Emu 100:125-132

Pliosungnoen M, Gale G, Savini T (2010) Density and microhabitat use of Bengal slow loris in primary forest and non-native plantation forest. Am J Primatol 72:1108-1117

Robjent H (2005) Nocturnal primates of the Ituri forest DRC: a preliminary study involving distance sampling. $\mathrm{MSc}$ thesis, Oxford Brookes University

Roos C (2003) Molekulare Phylogenie der Halbaffen, Schlankaffen, und Gibbons. PhD thesis, Technische Universität München, Munich

Schein L (2008) Species diversity of the enigmatic nocturnal primates in the secondary Rhoko forest, Cross River State, Nigeria: preliminary findings on densities, abundance estimates, and methods comparisons using Distance. MSc thesis, Oxford Brookes University

Starr CR, Nekaris KAI, Streicher U, Leung L (2011) Field surveys of the threatened pygmy slow loris (Nycticebus pygmaeus) using local knowledge in Mondulkiri Province, Cambodia. Oryx 45:135-142

Starr C, Nekaris KAI, Leung L (2012) Hiding from the moonlight: luminosity and temperature affect activity of Asian nocturnal primates in a highly seasonal forest. PLoS One 7(4):e36396

Thorn J, Nijman V, Smith D, Nekaris KAI (2009) Ecological niche modelling as a technique for assessing threats and setting conservation priorities for Asian slow lorises (Primates: Nycticebus). Divers Distrib 15:289-298

Trent BK, Tucker ME, Lockard JS (1977) Activity changes with illumination in slow lorises Nycticebus coucang. Appl Anim Ethol 3:281-286

- Voskamp A, Rode EJ, Coudrat CNZ, Wirdateti and others (2014) Modelling the habitat use and distribution of the threatened Javlon slow loris Nycticebus javanicus. Endang Species Res 23:277-286

Submitted: May 28, 2013; Accepted: January 23, 2014 Proofs received from author(s): April 6, 2014 